УДК 635.6

(C) 2012

Пузік Л. М., доктор сільськогосподарських наук,

Образцова 3. Г., кандидат сільськогосподарських наук

Харківський національний аграрний університет

\title{
ОСОБЛИВОСТІ ФОРМУВАННЯ ВРОЖАЙНОСТІ КАБАЧКА ЗАЛЕЖНО ВІД КЛІМАТИЧНИХ УМОВ
}

\section{Рецензент - доктор сільськогосподарських наук, професор Г. П. Жемела}

На основі багаторічних досліджень вивчено вплив суми ефективних температур повітря та кількості опадів за вететаційний період на врожайність кабачка, а також на основі статистичної обробки даних методами дисперсійного, кореляційного й регресійного аналізів із використанням пакетів Excel i Statistica встановлено, що мінливість урожайності була низькою (5,39\%), але поступалася сумі температур $(7,38 \%)$ і кількості опадів

(16,63\%). Статистичні параметри метеорологічних факторів і урожайності засвідчують, щуо

між урожайністю й сумою опадів та сумою ефективних температур існує незначна обернена залежність.

Ключові слова: кореляція, варіація, коефіцієнт еластичності, мінливість.

Постановка проблеми. Рослина може повністю проявити свої генетичні можливості формування високоякісної продукції лише за умов оптимальної забезпеченості всіма факторами життя: світлом, теплом, вологою, повітрям і поживними речовинами. Однак у процесі вегетації можуть спостерігатися весняні та осінні заморозки, похолодання, теплові пошкодження рослин, зміна посухи й надмірне зволоження, тобто оптимальні умови можуть чергуватися з несприятливими, а то й екстремальними умовами.

Аналіз основних досліджень і публікацій, у яких започатковано розв'язання проблеми. Залежно від зміни умов погоди урожайність i якість продукції суттєво різняться за роками. Тому дана проблема врахування кліматичних умов $\epsilon$ важливим як для географічного розміщення рослин, так і вирощування повноцінної продукції [3]. Кабачок - тепловимоглива рослина і водночас із-поміж усіх гарбузових найбільш холодостійка. Урожайність кабачка в Україні у середньому становить 16-20 т/га [1].

Роль води, що бере участь у всіх фізіологічних процесах, у житті рослини величезна. Разом із водою до рослини надходять і перебувають у ній мінеральні та пластичні речовини. Кабачок вимагає достатньої кількості води $[2,4]$.
Мета дослідження: вивчити вплив кліматичних факторів на формування товарної врожайності кабачка.

Методика досліджень. Для характеристики агрокліматичних особливостей України використовували вибірку статистичних даних щорічних оглядів метеорологічних умов Українського гідрометеорологічного центру Міністерства екології та природних ресурсів України за період 20032010 років. Вивчали основні метеорологічні показники: кількість опадів, міліметрів, суму ефективних температур $>15^{\circ} \mathrm{C}$, середньоденну температуру за період вегетації кабачка (травень - серпень) в усіх областях України. У своїх дослідженнях ми зробили спробу визначити роль ресурсів тепла i вологи на урожайність кабачка. Статистичну обробку даних здійснювали методами дисперсійного, кореляційного, регресійного аналізів із використанням пакетів Excel i Statistika.

Результати досліджень. Багаторічні дослідження стосовно вивчення впливу температур на урожайність кабачка в умовах України протягом 2003-2010 рр. свідчать, що сума ефективних температур повітря коливалася від 380,3 до $664,3{ }^{\circ} \mathrm{C}$ (табл. 1 , рис. 1 ).

Урожайність, як свідчать дані, в господарствах із різною формою власності становила 16,319,1 т/га. Амплітуда коливання температур становила $284{ }^{\circ} \mathrm{C}$.

Коефіцієнт варіювання за таких температурних умов дорівнював 5,39 (табл. 2).

За статистичного аналізу врожайності кабачка визначено різницю ï коливання $(2,8$ т/га). Така амплітуда вимагає встановлення критерію мінливості врожайності на $1{ }^{\circ} \mathrm{C}$ ефективних температур, що надалі дасть можливість прогнозувати продуктивність культури. Нами розрахований коефіцієнт еластичності (Е) для кожного року, який показує, на скільки процентів змінюється результативна ознака (урожайність) за коливання суми температур (X) на $1 \%$. Найбільше зменшення урожайності може бути у роки з більш високими сумами ефективних температур. Так, у 
2010 р. зі зміною суми температур лише на $1 \%$ (за рівних інших умов) урожайність могла б зменшитися на $0,074 \%$, а за нижчої температури, у 2007 р. коефіцієнт еластичності дорівнював $0,042 \%$, тобто на 0,68 т/га за урожайності 16,3 т/га $(16,3$ т/га х $0,042=0,68)$. Коефіцієнт варіації врожайності (V \%) був нижчий, аніж суми температур утричі й становив 5,4 \% (табл. 2).

Згідно з отриманим нами статистичним мате- ріалом за 8 років, залежність між сумою температур і врожайністю була оберненою $(\mathrm{r}=-0,197)$. Таким чином, зі збільшенням суми ефективних температур понад $430{ }^{\circ} \mathrm{C}$ урожайність кабачка зменшується. Так, у 2008 р. серед розглянутих років урожайність кабачка була більшою, а саме 19,1 т/га за суми температур $429,7^{\circ} \mathrm{C}$; при підвищенні температури до $558,2^{\circ} \mathrm{C}$ у 2005 р. вона зменшилася до 16,7 т/га.

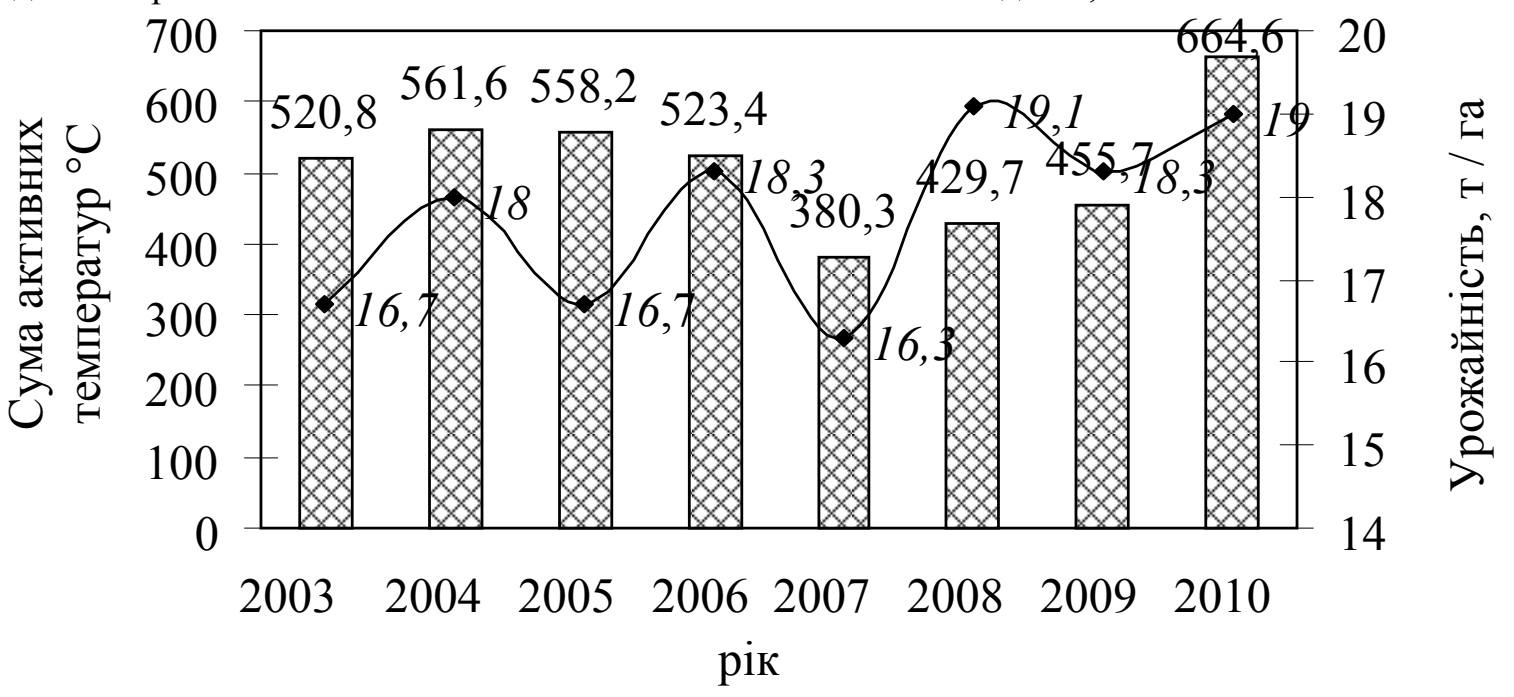

Рис. 1. Сума активних температур за вететаційний період і динаміка врожсайності кабачка в Украӥні: - сума активних температур; - -урожайність, т/га.

\section{1. Залежність урожайності кабачка від кліматичних умов (у середньому в Украйні)}

\begin{tabular}{|c|c|c|c|c|c|}
\hline Рік & $\begin{array}{c}\text { Урожайність, } \\
\text { т/га }\end{array}$ & $\begin{array}{c}\text { Сума ефективних } \\
\text { температур }>15^{\circ} \mathrm{C}, \\
{ }^{\circ} \mathrm{C}\end{array}$ & $\begin{array}{c}\text { Коефіцієнт ела- } \\
\text { стичності (Е) }\end{array}$ & $\begin{array}{c}\text { Кількість } \\
\text { опадів, мм }\end{array}$ & $\begin{array}{c}\text { Коефіцієнт ела- } \\
\text { стичності (Е) }\end{array}$ \\
\hline 2003 & 16,7 & 520,8 & $-0,060$ & 211 & 0,031 \\
\hline 2004 & 18,0 & 561,6 & $-0,062$ & 297 & 0,043 \\
\hline 2005 & 16,7 & 558,2 & $-0,062$ & 304 & 0,044 \\
\hline 2006 & 18,3 & 523,4 & $-0,056$ & 274 & 0,040 \\
\hline 2007 & 16,3 & 380,3 & $-0,042$ & 346 & 0,051 \\
\hline 2008 & 19,1 & 429,7 & $-0,048$ & 297 & 0,043 \\
\hline 2009 & 18,3 & 455,7 & $-0,042$ & 348 & 0,051 \\
\hline 2010 & 19,0 & 664,3 & $-0,074$ & 236 & 0,034 \\
\hline
\end{tabular}

2. Статистична характеристика суми температур, кількості опадів і врожайності кабачка в Украӥні

\begin{tabular}{|c|c|c|c|c|c|c|c|c|}
\hline Показник & $\begin{array}{c}\mathrm{X} \\
\text { сума тем- } \\
\text { ператур } \\
{ }^{\circ} \mathrm{C}\end{array}$ & $\mathrm{X}$ середнє & $\begin{array}{c}\mathrm{Sx} \\
\text { помилка }\end{array}$ & $\begin{array}{c}\mathrm{S}^{2} \\
\text { дисперсія }\end{array}$ & $\begin{array}{c}\mathrm{S} \\
\text { стандарт- } \\
\text { не відхи- } \\
\text { лення }\end{array}$ & $\begin{array}{c}\mathrm{V} \\
\text { коефі- } \\
\text { цієнт } \\
\text { варіації }\end{array}$ & $\begin{array}{c}\text { Sх\% } \\
\text { точність } \\
\text { досліду }\end{array}$ & $\mathrm{HOM}$ \\
\hline $\begin{array}{c}\text { Урожайність, } \\
\text { т/га }\end{array}$ & 144,8 & 17,8 & 0,343 & 0,92 & 0,9599 & 5,39 & 1,92 & 3,30 \\
\hline $\begin{array}{c}\text { Сума темпера- } \\
\text { тур, }{ }^{\circ} \mathrm{C}\end{array}$ & 4094,3 & 511,8 & 31,77 & 7912,7 & 88,95 & 17,38 & 6,2 & 29,44 \\
\hline Опади, мм & 2313 & 289,1 & 17,17 & 2314,4 & 48,10 & 16,64 & 5,94 & 17,37 \\
\hline
\end{tabular}




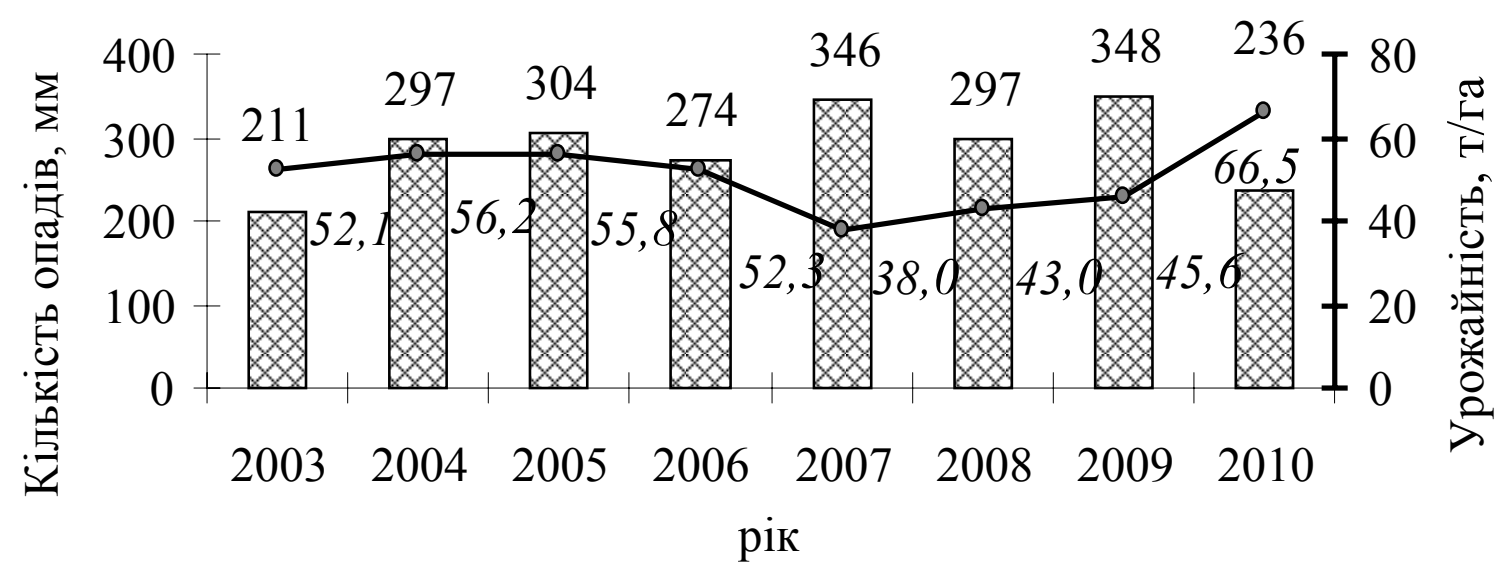

Рис. 2. Кількість опадів за вететаційний період і динаміка урожсайності кабачка в Украӥні: - кількість опадів, мм; $\multimap-$ урожайність, т/га.

Тобто, на суму температур $128,5^{\circ} \mathrm{C}$ урожайність знизилася на 2,4 т/га (при підвищенні температури на $1{ }^{\circ} \mathrm{C}$ урожайність статистично зменшилася на 18,7 кг/га). Успіх в отриманні ефективного наукового матеріалу базується не тільки на пізнанні біології рослини, а й на встановленні динаміко-фізіологічного внутрішнього ії стану гомеостатистичності. Гомеостатистичність культури кабачка за урожайністю була низькою - 3,3, за сумою температур - середньою.

Статистичний аналіз доступу води до рослини внаслідок опадів свідчить (у середньому по Україні), що протягом вегетаційного періоду 2003-2010 рр. їх випало 2313 мм, тобто при середньому значенні за рік 289,1 мм. Більш дощовими виявилися 2009 р. - 348 мм, 2007 р. 346 мм, 2005 р. - 304 мм (рис. 2).

Варіювання суми опадів було середнім і становило $\quad 16,64 \%$ при гомеостатистичності $17,37 \%$. Порівняльний аналіз дії різної суми опадів на формування врожайності кабачка був таким: сумарна врожайність за вісім років становила 142,4 т/га при середній 17,8 т/га, тобто була у 16 разів меншою. Для формування середньої урожайності $(17,8$ т/га) сума опадів за рік повинна становити близько 289,1 мм. Мінливість урожайності (V) у господарствах різної форми власності знаходилася на рівні 5,39\%, тобто на

\section{БІБЛІОГРАФІЯ}

1. Горкавий В. К. Статистика / В. К. Горкавий. К.: Вища шк., 1994. - 408 с.

2. Сазонова Л. В. Корнеплодные растения: морковь, сельдерей, петрушка, пастернак, редис, редька / Л. В. Сазонова, Э. А. Власова. - Л.: Агропромиздат, 1990. $-296 \mathrm{c}$.
$11,25 \%$ меншою, гемеостатистичність урожайності - на 14,07 \% нижчою порівняно з сумою опадів. Різниця між максимальною (348 мм) i мінімальною (211 мм) кількістю опадів знаходилася на рівні 137 мм за різниці урожайності 2,4 т/га. Проведений кореляційний аналіз засвідчив незначну обернену залежність $(\mathrm{r}=-0,133)$ урожайності кабачка від суми опадів, коефіцієнт регресії (з рівняння регресії $\mathrm{Y}=18,55-0,026 \mathrm{x}$ ) вказує, на скільки одиниць змінюється результативна ознака. Визначено, що зі збільшенням суми опадів на 1 мм урожайність зменшується на 2,6 кг/га. Крім того, коефіцієнт еластичності свідчить, на скільки відсотків результативна ознака (урожайність) зменшиться зі збільшенням суми опадів на $1 \%$. Більший коефіцієнт еластичності 0,051 спостерігався у 2007 та 2009 роках.

\section{Висновки:}

1. Мінливість (V) урожайності кабачка протягом 2003-2010 pp. в Україні була низькою $(5,39 \%)$ і поступалася сумі температур $(17,38 \%)$ та кількості опадів $(16,64 \%)$ за період вегетації.

2. Статистичні параметри метеорологічних факторів і урожайності засвідчують, що між урожайністю й сумою опадів та сумою ефективних температур існує незначна обернена залежність $(\mathrm{r}=-0,133, \mathrm{r}=-0,197$ відповідно $)$.

3. Шарапов Н. И. Климат и качество урожая / Шарапова Н. И., Смирнов В. А. - Л.: Гидрометеоиздат, 1966. $-128 \mathrm{c}$.

4. Эдельштейн В. И. Овощеводство / В. И. Эдельштейн. - М.: Сельхозиздат, 1953. - 487 с. 